\title{
Research and Application of Vocational Ability Training__Take Computer Application Technology as an Example
}

\author{
Ying Wang* \\ Guangdong Vocational College of Post and Telecom, Guangzhou 510630, Guangdong, China. \\ E-mail: 158356814@qq.com
}

\begin{abstract}
To better improve the professional ability of students is the focus of talent training in higher vocational colleges in China in the new era. The Computer major is a relatively popular major in China's higher vocational colleges. With the continuous development of higher vocational education, the issue of professional ability training for computer majors has attracted widespread attention. This article starts with the analysis of the problems existing in the training of computer professional vocational ability, and focuses on the research and application of computer professional vocational ability training. It is hoped to use the professional ability as the starting point to further optimize the vocational ability training model of computer science in higher vocational colleges in China and provide more application-oriented computer talents to the society.
\end{abstract}

Keywords: Computer Major; Professional Ability; Training Research; Training Application

With the development of information technology, various industries have begun to involve big data technology, the Internet of Things technology, cloud computing technology, etc. These emerging technologies basically belong to the field of computer technology. In such a general environment, all walks of life put forward higher work requirements for computer personnel when hiring staff. In order to better promote the employment and entrepreneurship of higher vocational students in China, it is of great practical significance to pay attention to the professional ability training of computer majors.

\section{Problems in the cultivation of professional abilities of the computer major}

\subsection{Students generally lack professional awareness}

To cultivate students' professional ability, students must first have professional awareness. At present, computer majors in some vocational colleges in China generally lack this kind of professional awareness. The reasons leading to the lack of professional awareness of students are mainly in these aspects. On the one hand, in the computer majors set up by some vocational colleges, teachers pay too much attention to the explanation of professional computer knowledge and ignore the training of professional ability. Vocational students spend most of their time on campus[1], and their social experience is limited. If teachers do not provide the necessary science to students from the perspective of career planning, students' professional awareness will be weak. On the other hand, in some computer majors offered by vocational colleges, although teachers will explain some employment situations in the computer field, such explanations are too abstract and it is difficult for students to have a clear understanding. Moreover, the employment prospects of computers analyzed by some teachers do not fully integrate the actual conditions of today's society. They are mainly analyzed from the perspective of public institutions and large enterprises, making students feel that they are "castles in the sky" and it is difficult to really touch this kind of employment opportunity. If things go on like this, students will feel that the career planning explained by the teacher is unrealistic, and they will not have the enthusiasm for deep

Copyright (C) 2020 Ying Wang

doi: $10.18282 /$ le.v9i6.1286

This is an open-access article distributed under the terms of the Creative Commons Attribution Non-Commercial License

(http://creativecommons.org/licenses/by-nc/4.0/), which permits unrestricted non-commercial use, distribution, and reproduction in any medium, provided the original work is properly cited. 
understanding.

\subsection{The unreasonable setting of talent training goals}

In the process of cultivating students' vocational ability, higher vocational colleges need to set talent training goals. However, in actual situations, the talent training goals set by some higher vocational colleges for computer majors are unreasonable. To be clear, first, the computer majors set up by some higher vocational colleges lack a certain level of talent training goals of Career-oriented, but mainly based on the student's computer professional performance as the goal. Under such a talent training goal, students will emphasize theory and neglect ability, which is not conducive to improving students' professional ability[2]. Second, some computer majors set up in higher vocational colleges will advocate training students' professional abilities. This kind of proposition only stays in theory, and colleges and universities have not formulated a series of specific professional ability training programs around this goal. Moreover, in the assessment of computer majors, professional ability is not included in the comprehensive assessment of students. If the goal of vocational ability is in vain, it is difficult to really attract students' attention.

\subsection{There are obvious shortcomings in practical teaching}

If you want to effectively improve the professional ability of students, only through theoretical knowledge is relatively simple. At this stage, the practical teaching of computer majors in some higher vocational colleges in China is obviously insufficient, which seriously hinders the vocational ability training of colleges and universities. On the one hand, in the computer majors set up by some vocational colleges, teachers spend most of their time and energy on the explanation of theoretical knowledge, and do not pay enough attention to students' computer practice[3]. There are many reasons for this phenomenon. Among them, the backward and lagging of hardware equipment is a very important reason. If the students' computer practice level is relatively low, it will easily affect the students' future employment. On the other hand, in the computer majors set up by some higher vocational colleges, teachers have not actively expanded off-campus practice learning platforms, and students lack communication with corporate employees, as well as the opportunity to learn. Under such circumstances, students will lack the understanding of the actual employment requirements of the computer industry, which is not conducive to the targeted improvement of their professional abilities.

\section{Research and application of professional ability training for Computer majors}

\subsection{Provide practical employment guidance and cultivate students' professional awareness}

How to cultivate students' professional awareness? On the one hand, for the computer majors offered by higher vocational colleges, teachers should not only pay attention to the explanation of computer professional knowledge, but also pay attention to the cultivation of professional ability. Teachers can reasonably infiltrate career knowledge, social etiquette, management skills, etc. in computer teaching, so as to improve students' professional ability in all aspects; on the other hand, for the computer majors opened in higher vocational colleges, teachers should explain the employment situation in the computer field. It is necessary to conduct necessary market research, understand the latest employment trends in the computer industry[4], and bring practical employment references to students. Moreover, when analyzing career planning, teachers should not only analyze from the perspective of public institutions and large enterprises, but also fully integrate students' diverse employment needs to provide practical employment guidance. In this process, teachers should encourage students to establish a positive outlook on employment, choose jobs on a large scale and through multiple channels, and reshape students' confidence in employment and entrepreneurship.

\subsection{Reasonably set talent training goals and strengthen career-oriented education and teaching}

Regarding the setting of talent training goals, higher vocational colleges can improve from these aspects: First, the computer majors set up by higher vocational colleges must strengthen the career orientation in the setting of talent training goals, and not just use students' computer professional achievement as the goal. After establishing a professional-oriented talent training goal, teachers should improve students' vocational abilities through every detail of education and teaching. For example, when explaining word-related knowledge, teachers can infiltrate some job hunting and job selection content from the perspective of making job resumes. Second, for the computer majors opened 
in higher vocational colleges, once established the "career-oriented" training goal[5], this kind of goal cannot just stay in theory. Colleges and universities should develop a series of specific professional ability training programs around this goal. For example, when explaining Excel-related knowledge, teachers can give specific business cases from the perspective of corporate statistics, and let students use Excel to deal with corporate sales data. Through such computer practical exercises, students' professional ability can be improved well. In the final computer assessment, teachers can also set up career-oriented exam questions from these perspectives to test students' professional abilities.

\subsection{Actively expand the off-campus practice learning platform to understand the professional needs of the company}

In order to better enhance students' professional ability, higher vocational colleges should attach great importance to practical teaching. On the one hand, in the computer majors offered by higher vocational colleges, teachers should pay full attention to computer practical exercises. For the problem of backward and lagging hardware equipment, teachers should actively strive for the necessary education funds to improve students' learning conditions. With the popularization of information equipment, teachers can also encourage students to practice computer operations in the dormitory or at home. In this process, teachers can use the form of micro-classes to assign computer practical tasks, guide students in the details of computer practical operations, and improve the effectiveness of students' computer practical operations. On the other hand, for the computer majors in higher vocational colleges, teachers should actively expand the practical learning platform outside the school, so that students can communicate and learn with employees of the enterprise, and understand the professional needs of the enterprise. In this process, teachers should strive for the support of school leaders, give full play to the school's resource advantages, and build a long-term school-enterprise cooperation mechanism for students, so that students can gradually improve their professional abilities in practical learning.

\section{Conclusion}

With the continuous development of computer technology, the penetration of computer technology into all walks of life will become more and more obvious. For higher vocational students in the new era, improving the professional competence of computer science is a predictable career plan, which is conducive to better employment and entrepreneurship in the future. It should be noted that in the process of cultivating students' professional ability, higher vocational teachers should be good at stimulating students' sense of innovation and cultivating students' innovative ability. The computer field is changing rapidly, and only innovation can bring forth the new breakthroughs and can effectively improve the competitiveness of students in employment and entrepreneurship.

\section{References}

1. Li H, Zhang M. A preliminary study on the "Four-party cooperation" mechanism for training computer professionals in higher vocational colleges. Science and Technology Vision 2019; (02): 79-80.

2. Zhang $X$. The practice of higher vocational computer basic teaching reform based on application ability. Science and Technology Innovation Herald 2019; 16 (17): 197-198.

3. Li B, Li Q, Ni C. Research on Robot Informatization teaching reform in computer basic courses. Science \& Technology Monthly 2019; 32(04): 86-88.

4. Xu Y. Research on the path from "Artificial Intelligence Education" to "Educational Artificial Intelligence". China Audio-visual Education 2018; (12): 81-87.

5. Zhong S, Tang Y. Research on the direction and path of educational innovation in the era of artificial intelligence. Audio-visual Education Research 2018; 39 (10): 17-22+42. 